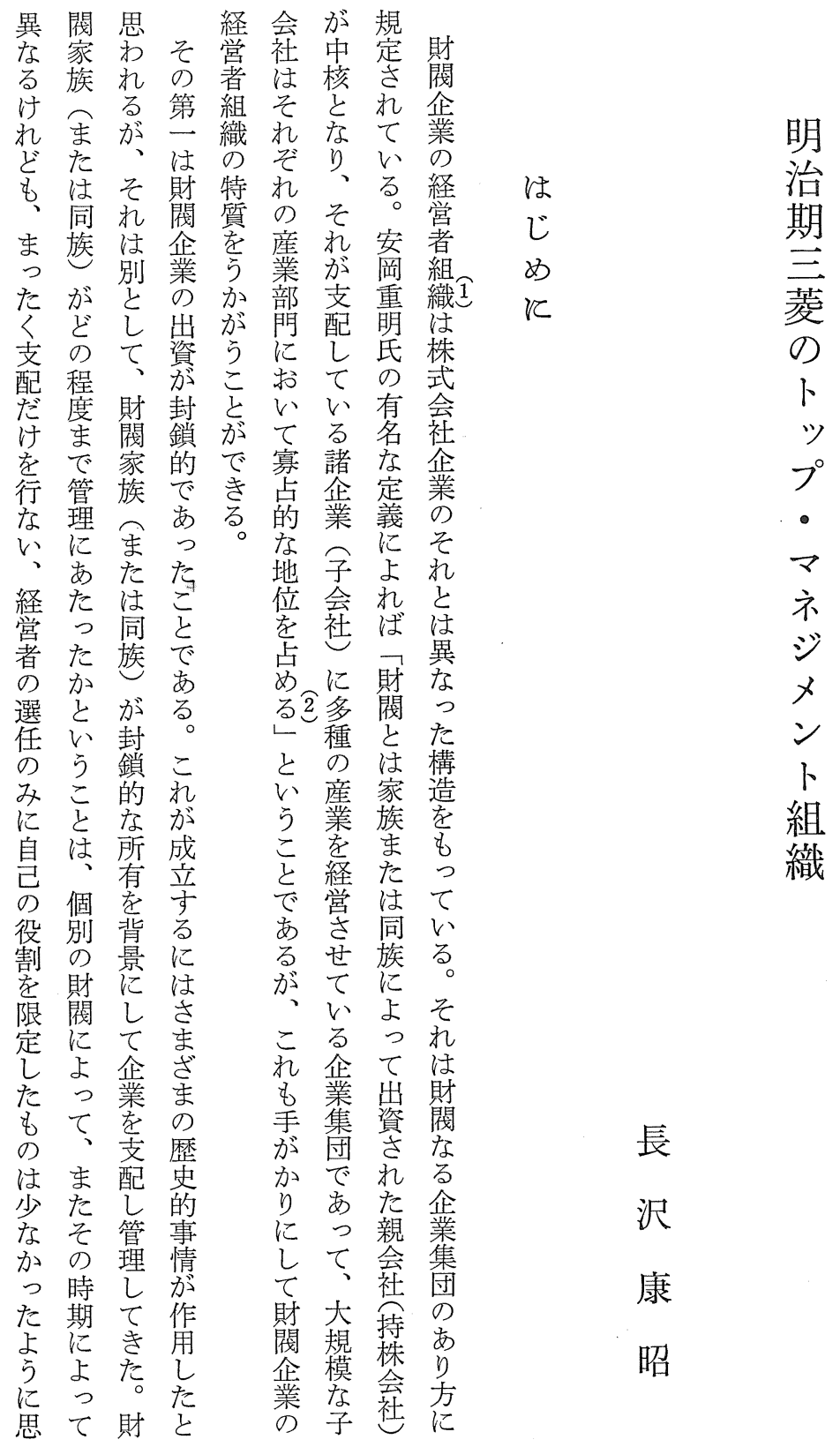


几生位倒お 等各の構式違的会別等わ どしを的り本多財コ造会周の形社に第机 なな占に、稿く閥ンを社知中態の子云る くかめ大明は の の

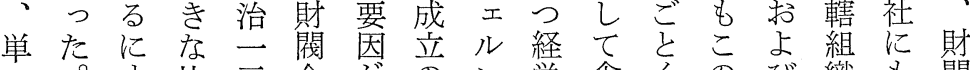
一。す比三企がのン営傘くのび織も閥 企まぎ重年業作事形者下、三々と経家 業たなをごの用情態組事明つれな営族 の明かむろ経し織業治のららり者乞 直治っつに営た事到を部未次の、組ま 嫦期たては者も業達法門加元間子織た 部の招組の部し的のらのの会加は 門三こりぼ織で門た。経大異権社形同 と菱の、その あの後制営正な限の成族 しはたなの事ろ性の度管期ると経さ て めた原例う。格三的理に経職嫦れと 心銀傘海型研。と重にに営能者る彼 た行下運が究規の整あけ者の組こら 加。事業出と模経備たて、組分織と方 ら倉業放来し、営すら、織担はに選 、庫部椠上て 財者るせいは関そる任 事業門のが、閥組にるすす存係れるこ

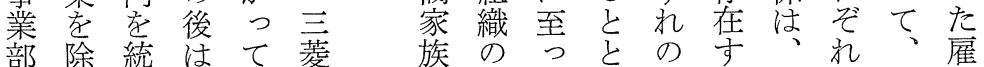
部除統はて 菱 族の権た


のて、尔山た取限。に閥別事営経

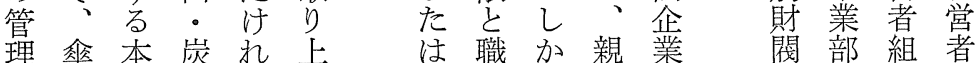
組下社坑どげ同能し会に采織に 織 事 組 業 す る

と業織㤎事そ三

そ荫形業の菱 れに成のこの ら独守中 孝立る心に合 統し必とは梳 轄た要な海 守法 性り運 創 る人は、業業 本形明他吕以 社態治の畜 来 組妾严事多 織与 $\bigcirc$ 業 事 角 とえ年部業経 㤎方代門部営 企こには門を 業と大従の行 内はる属中な のほま的でつ 経とで地疰て

族のこ社㧤 関のにい

お係コはて よ注ン合す び、ッ名コ 雇各エなン 用財ルいツ 経閥ンしエ 営に形合ル 者よ態資ン のつに会形 指て 到 社態 導異達主橓 力な方吉採 のつるる用 強て過こい さい程とで子 程。捜、会 度こ㤂重社 等 はこ株
よの沈よ つ管 三 つ て理重て にの親 まあ構 会 たた造社 そるをの のこと経 時とる嫦 期に点者 になが組 よる。挙 織 て 親ら形 異会机成 な社るさ ると文親 、会会こ そ社社机 のの はと 相法子は 


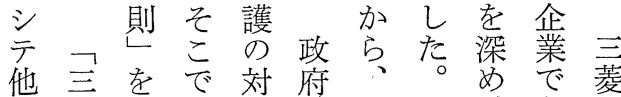

菱制政象注自ま、ああ

資汽定府を海然たそつ発

金船しは転運発海のた释



募社。菱し保的業護文関

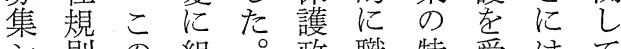



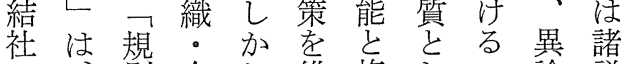

ス、則会し維権しこ論説

ルそ社至新限てと肪㤎

者のに制菱直の、になあ

冒よ度妿後構支よいる

大頭つを組よ造社つとが

異でて 整織 り架唯 生地、思

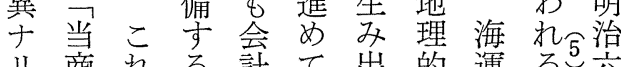

リ商れる話て出的運る。宍

故会まま制きされ部。年



社 筑請未怙急四に

三会発し確征た散激月三

関 社生、立台

ス, 的 三のの

ル名に菱ま役

一习形はまを

切命成こで契

ノシされは機

事会れを本に

及社た受格し

七組忊的七

隹体織てな

貺 $\Rightarrow$ 方、保日

黜 成集 明護 本

陟 等治孝国

等下成分行郵

都雖さ年な便

テモ五う蒸

社其、严こ汽

長 実明、と船

全確 至会

特クに三で 社

裁一規菱き吕

习家定汽なら

仰了さ船加至

事れ 会つ菱

ク業た 社た 保
しにに川

、拡 本 商

乙大 社 会

かしをを

そた重 王

れ規に商

ら模 移 会

の しと

間拡た改

の大こ称

緊はろし

密組よた

な織り、こ

絡形三に

調成菱 は

整すは

がる 政 岩

必必府 崎

要 要と 弥

で 性の太

あ孝結 郎

る生びの

こ出き個
そ 以少 営

ぞ上にダ織

れのな、に

考よつ。シ 埋

察 5 た出没

て 特 プし

ゆ質強、下

こ学文

事と

京菱業令

多ル

角 の

的 関

プ拡係

$\therefore$ 大

亦伴て

ジ らあ

メ傘 ら

ン下わ

卜事和

組業る

織部 こ

のに

明経な



期 組

明織さ

治形に

中 成 期

期 は菱

明には

治分初

期化 代

明方 太

治向 郎

末 で以

期 行 来

にな 岩

分 わ崎

讨家 
経 営 史 学



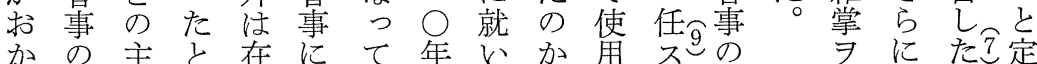

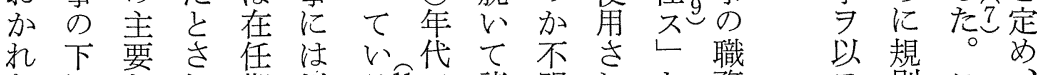

たにな机期沁帒で諸明れと務

本支る間田しは方でていは

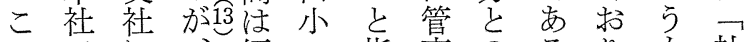

のでに、短一指事のる・りを社

制は出こい郎摘の脚が、の長

度運張の。、し任合、こでノ

は用しょこ石て務等明のあ命

明課、られ川いにを治こり、

治事業にら七る軽取兰ら、受

一務務明管財它重扱年古支示

五長を確事斯このふので配会

年指にの森ら違者何市に人社

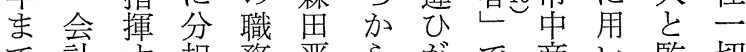

で計主担務晋らがで商い監切

め課るさ方、㐫社ら查先

ま事これ分管るるでれ役事

ぐ務々て担川事。とはての務

る長にいは村は右さいい職

し、なた、众市執た務総

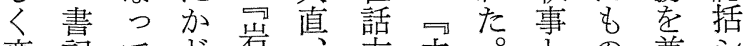

変記てど不崖立。との兼泣

更課いう崎浜的社ま並で补出

さ事た吕您鱼な体たん市た納

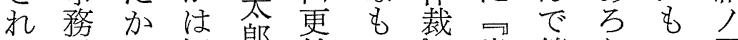

た長占疑郎始の岩管う。の正

本監あでに荘ら規弥染な管な

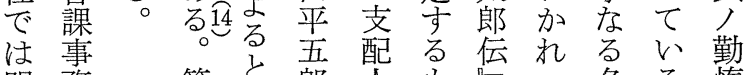

明務管々郎人も名る惰

治長事方的ので俗称。能

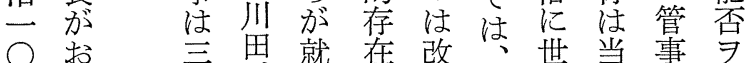

年か齐が任公訂子話時な調

く机鉱しと後明方どる查

ら 公山た変の治との 名至





に: 服、思の、制に普治長

運各、石、加管施相遍七三

用船神荝石車行当性年具

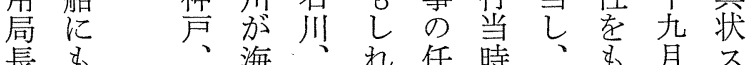

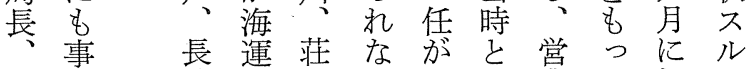

会務崎運装、重明業て初了

テ 則こ

之での三

另陣菱

副、頭

夕役指岩

ラ 貸 揮 崎

シ型 家

入順のの

小芧 社 事

使序長業

管独で

以管裁あ

宁妻る

外等義

切会太

少社 郎

使 般

役般死社

供事後 長



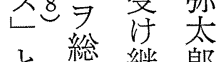

定括継郎

め、导机最

職 事 三経

制事菱営

管䀜伝者

事 寻統亦

事宁なる

務課今兄

矛課た变

事店京

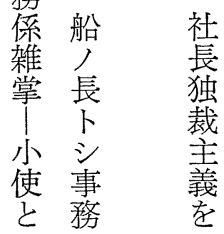


に締面の ら

定 ヨとるれ治

は支治 査 計

上役方国れ明㤎以驾も役局

つのな立た治こテでの毎三社化支五、長

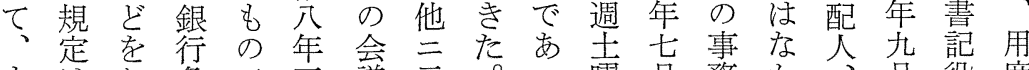

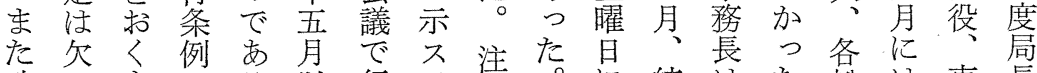

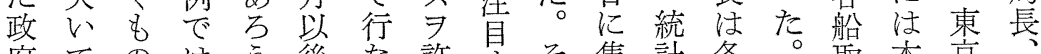

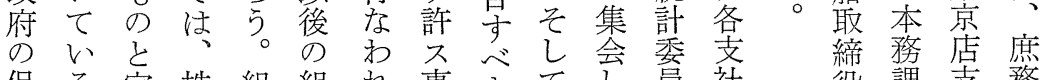

保る 定株 組組 れ



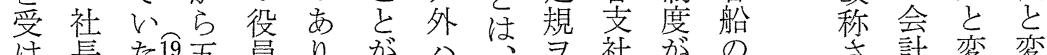

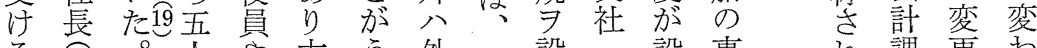

る碩人方

た頭三以出注人統方各け務

め取菱上資、加工計各船ら長

に!沙の者おお八委社よれと

支岩取とそ机勿員各りた注



織人家役別く。社調䈔、な

の|の字さ当查命告こり

整各所選机時

備 分有びるの

学課に汇会

行とな取こ社

ないる 締ろ制

つう\&役の度

た組の加重に

三織でら 役 関

貝査命䒚学、

タルテ整は、

リ事施 理 管 ッ

卜件行 し 事 プ

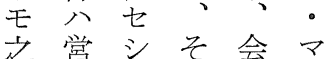

栄么れ㗝六

告, ‘方ジ

菱の文頭制 す

ク機 キ 基勘 メ

に構り取度る

と成、を存知

ル密件礎定ン

习 二 ᄂ

つはま選ほ識

て国た出ぼを

許涉 はし

サル: 書 政



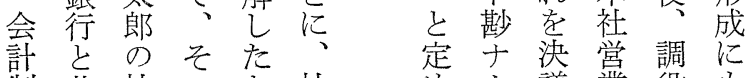

制共社のとと社

度通長下

め力議業役も

て $の$ 上立参

にし独にわの

拉七裁支机必

いい主配る要

てる義人、性

政。に、明学

府 政よ書 治 勘

の府つ記五案

いザ上ノ東加

るル社要京し

こ㠰長件店た

亡故の 引支よ

で 三裁調配 ら

た壴長さ

こ庶たさ

の務。ら

よ課とに

う長の 明

にの 後治

ミ課方二

ド課 方 三

・締三

マ整役层

亦理比

ジさ営は

メれ繬 会

ンた 方計

は各締 勘

職支役定

務 社、役

- 各 調

名 船 役用

称のな度

重会を統であ

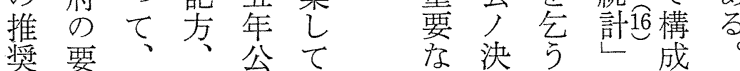

奨要聙取公て 布 作 決議こす威

加事 亡゙方

変務 方 元

更長 加 締

さ无え 役

れ 明ら

た治れ迴

が二た类

そ年こ取

の 三 れ 締

権 月 5 役

限には

に各明検 
経 営史学

方れを 蔀て修 い

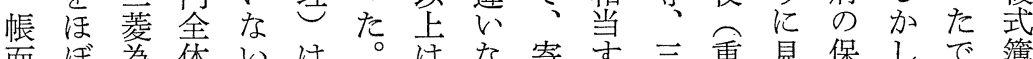
面ぼ為体い:は。寄す重見保しで簿

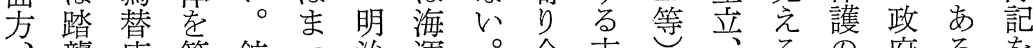

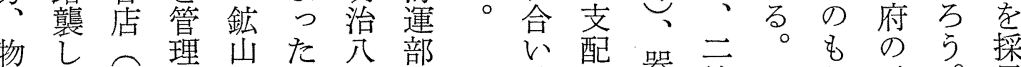
品て 明守。广年鹏世哭等日示。用 鑑い治る炭外ごの带孞械方本にしまし 定る三組坑人弓組余方方国あたたた 方。三織に任閉織亦如乞等郵つ壬江の

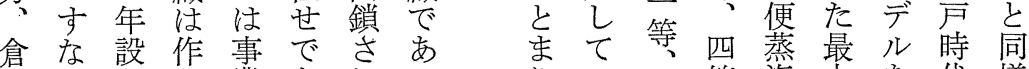


方ち、れ椞つたて、㤎る 等要船の無吕に 倉本很な がこた 樟他 加


差ノ倉た事く造事た国等役は社に統組

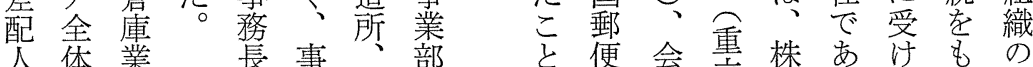

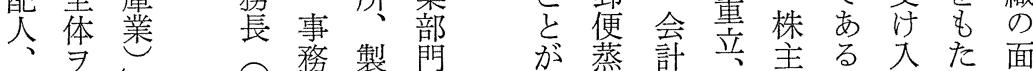

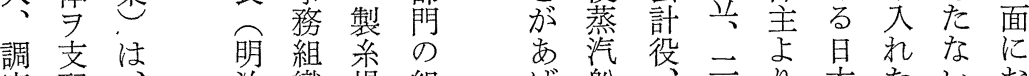
度配、治織場組げ船、等り本たいお 方会織方会火等頭国の 三い

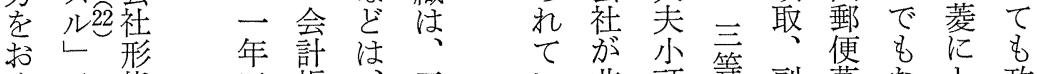
く元態 言帳主 い非頭等副蒸な と政 。締は簿資菱る能、四頭汽さっ府 ま採、㴹為 た口用元市架替 金内 L締べな店 銀部な。役ていと - 取少英た手 帳締つ改国め川 簿 $\exists た$ 称式不水 、行23け年明道 文机があ枟 書うどおうあ社 等支名加たる。索 検公そ配点三除 查をの菱て 行き織管る 鉄き


うと国に一 検の立 あ資造て 查下銀た料船未 役に行法整 お納そ 出つ舶俑

が率賄等取船そての 、等等会う、定 支、小を選社でこめ 配三頭热出のあれた 人菱学きし経る。国 のと抒、営。行立 欠のく組明な銀 如競亡各の織治ら行 女争定船下至八の制 そにめでに主年は度 の打法菱当よ起 重くい船社は時りモ 要れる20長監 あ、容 なを省ま三易ル 要亡こ下惩り菱でと 茵っこに厽市市 のたで連各考 ラつる

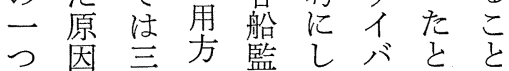


あ一の二役かでわ必 つつ管等得つあれ要 たと事書たり、るで 
学、複 務 残

サ事の定机治

ス合務 所迕た二

し規有を鉱八

と程 者 定山 年

定 にめ。二

めでよ、炭

は方岩坑月

弥口結 崎 坑

太当社家造早治

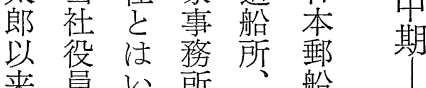

来員 以乺 船

のノ い学銀会

社進吕言行 祬鉱

独及w社水設

裁七。道立

主業そ唱なさ



をノそるの虫

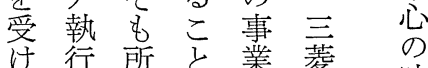

け行所㱏菱

継公有亡学

以細権し基 海

だ 大自た礎運

弥惁㤎三し門

妄社明菱て を

加艺では三つ

引寻 そ菱た

き示な の の 命加名 再

う不っ 称建太

きへた名郎

社 シ 加らはの

長他ら- 化

とノで見つ後

な役あ会た 社

り、員る。

明シよ治な

治テう枱っ

二決に九て

四 シ 思年い

年テわ兰た

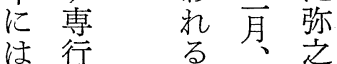

は行架、公

留儿事注
た24一園管 別任 ほ か 一店海理邸乙加同れ 年忐運問にた 設業題給 月咕は水社の明重 ら亦生市長 三 治要 本机ま志るっ菱二な 社、りな目頭関三決 に海に加的係年定 内運巨つで、者に注 方以大た水卧に設毎 㤎外でか 道監よ立週

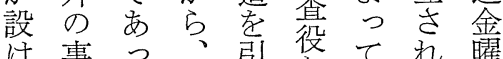
汀事っ、引役て机曜 ら業た支いな所た日 れをた配た㳊有千に 統め人も開 鉱轄かた心な机水加 山告、豆加道机 -る海で心つ株会る 炭こ運こ沿た主社社 坑と以を道この注長 はに外足住こう有管 こしの り 民の限事 のた部たに会よ責元 支唯間のも社り任締 配、ので給は三会集 下翌管 あ水を名社会 に年理らしと名しで お六組引た多取株定 加織。も立締式め れに営役会ら た廃はで業㤎社れ が㱑意あを選のる さ肪了主出先こ えれ払标貝岂駆と も社れ 従に態な ま長な 業す取垫り た直か員る締の 翌轄っ \& 役形取 年とた数のの締 三な。名でらと役 月っ 明程なち会 にた治葉く名た。 社そ年岩台株割 直の轄後 俥複の全弥た さ明、雑駒を寺し れ治梅な込兼郎た。 
管各し 書こ一管船船鉱郎人、け社し 就学

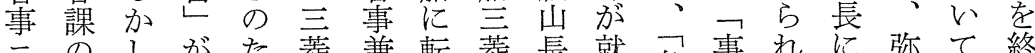
二のしがた菱兼転菱長就各事机に弥て終

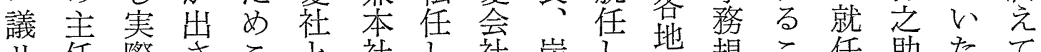
リ任際さこと社し社孷し垃規こ任助たて

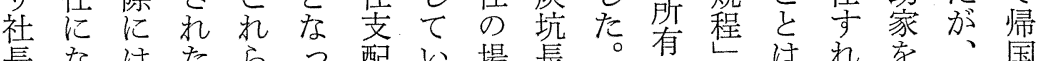
長なはたらっ配い場長。有他はれ学、国

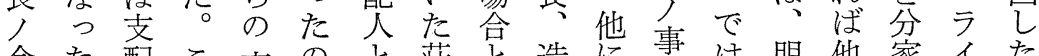
命た配こ事のと荘と造に事は明佯家イた







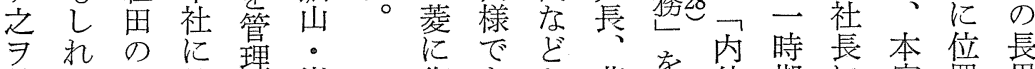

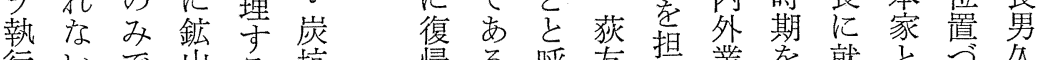

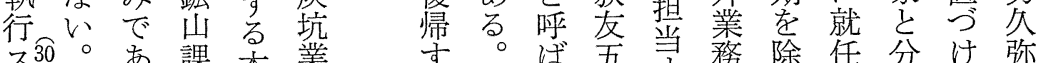

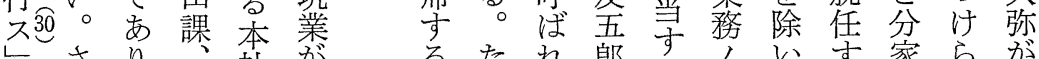

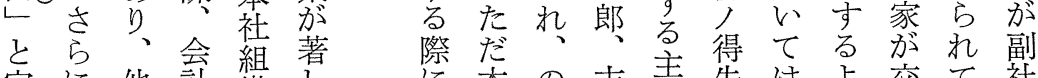
定に他詰織しに本の吉主失はよ交て社

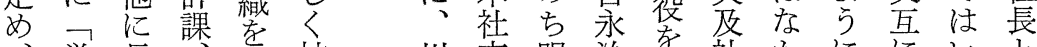

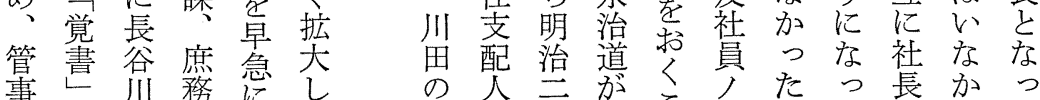

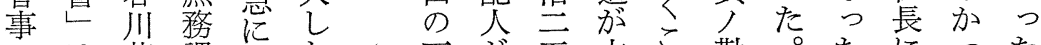

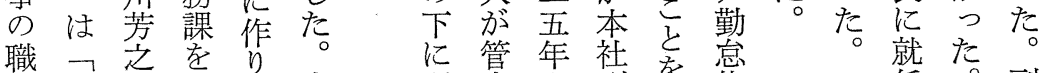
能三 助設 出事所事六副を总能こ任。 副 を課老け等業、属の月支定否の市人社 明ノ加る必所さ下に配な

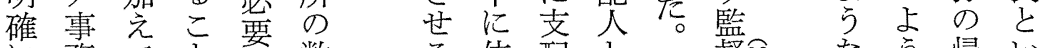
に務て と数学位配と管督なら帰い し八四、迫吕た置人な管尘相に国ら

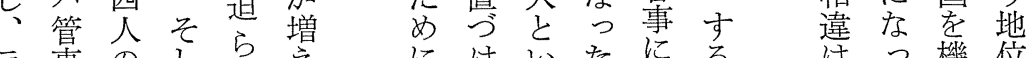

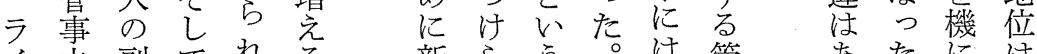

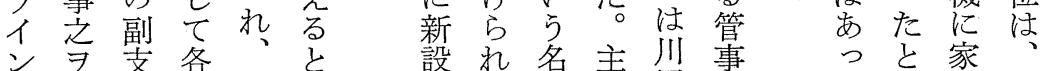



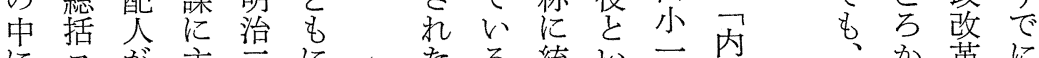

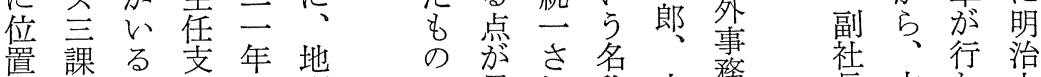
置課る 支年地を配一理 の゙㤎さ名称本務 社、行治



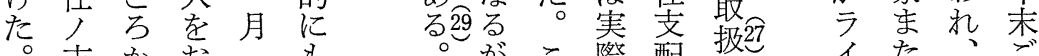

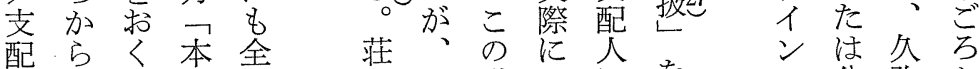
人こ社国思こ職はに文分弥か 分副と事に注制用は行 中家家ら 其支を務拡ま注い荘な深を弥 事配定取方文日郵ら田 5 位二本之 務人挑本便禁平支置方家助

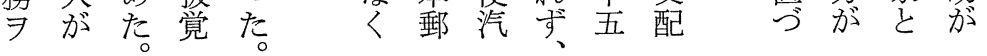






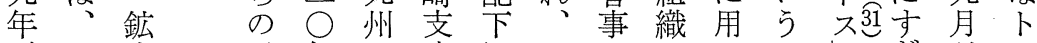
ごこ山手年の后にこはのい二டぎ以ッ らの直代売は㧤の高手る個亡な後プ か時炭し前炭九かた島直この定かの・ ら期坑を半店州机め崖しと事めつ海マ

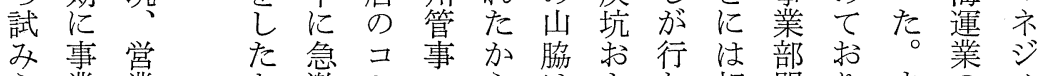
ら業業と激ミのらはよな相門りまのメ

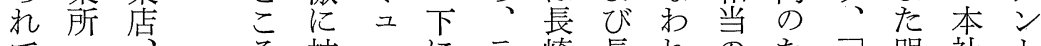
て ろ搪二にラ崎長れのた覚明社卜

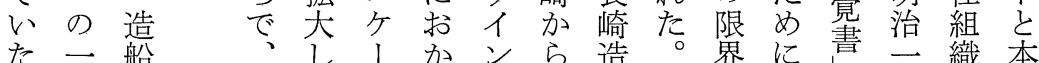

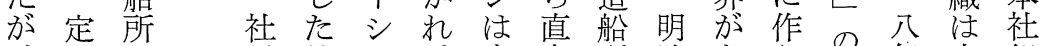
のと長鉱 $\exists$ 本方所治あら管年本組

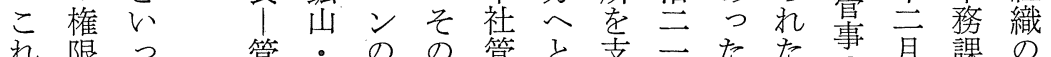

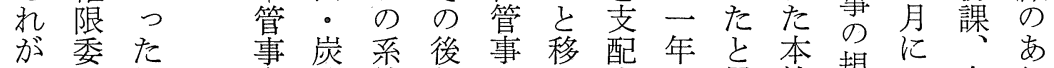

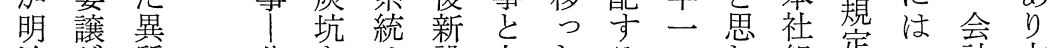

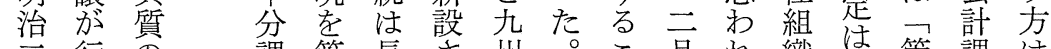
三行の課管長さ州。こ月、織は管課注

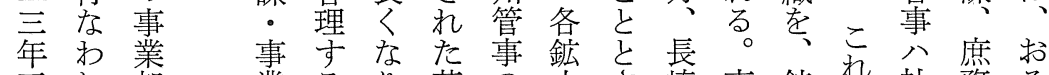
五れ部業るり若票岀さ崎事鉱杂社務々 月た鹏所た、松三执机実山受長課ら

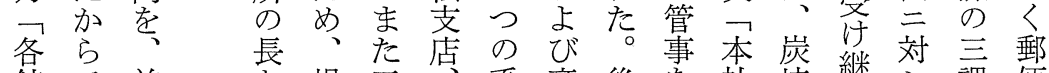

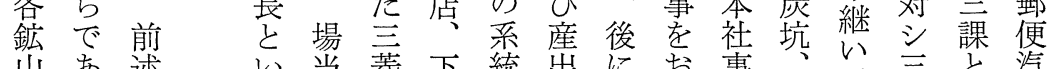
山岁述当菱下統出に掠事、声と汽 事るのうう社関に金新く務営た課な船 務。ご組的の支分属入こ取業の長つ言


报業きの組織は販鯰加覚学行お会 心所本大織全長る筅笛決書造要スり、社 得へ社枠亏体崎こをな定是船る。ル、の の組少くも支と行どさが所所覚そ

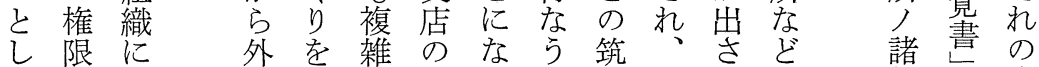
て委お机な支つ大豊山机の般で直 完譲いるたも配た阪站脇て異事は接 成はてを結の卡支炭正二質務本的

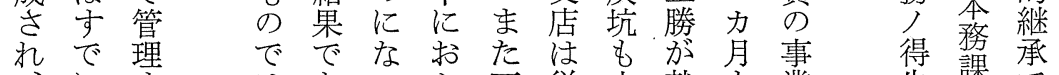






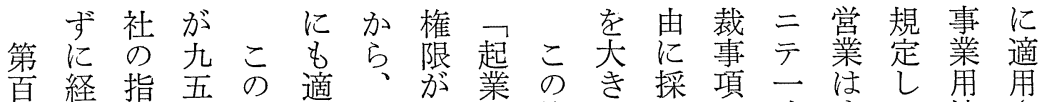
十営図 \% 時用本委費権々用と時すて地さ 九学に、期さ社袞し限軽、し人べ、買机 国れよ後に狆はさと委減昇た暇て本入た



銀よてが菱。事、てにるる雄業の都そ 行 う管严社業資本対こ解こ社所権亏机 でで理 $\vec{\bigcirc}$ 㫹本社応亡雇机員長限新

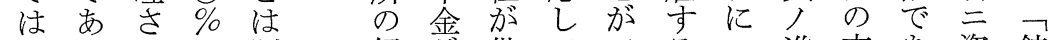

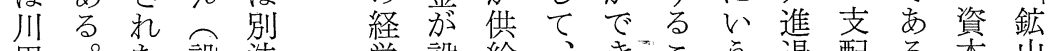
田。た設法営設給、きこう退配る本山

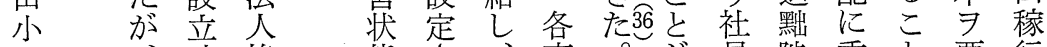
- 、時格、態さ 、事怔員陟委亡 要行



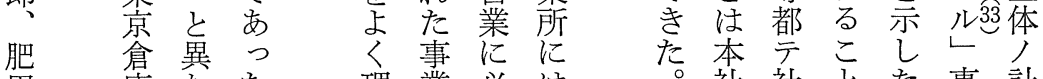


作社、の娄な定学用公起を、

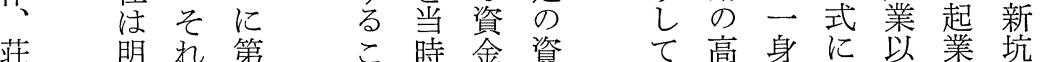
荘明れ第元時金資㢳高身に証業坑

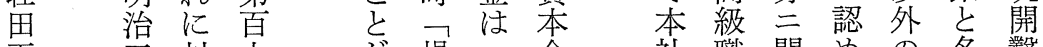
平 三対十 場二金 社職関めの名錅 五 三応九卆所定㤎 注員スた事ら

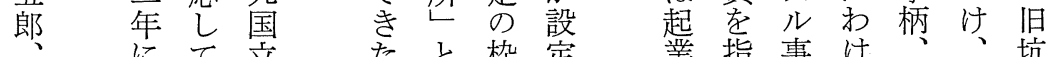

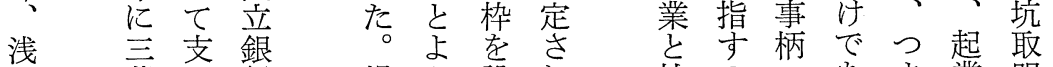
思菱配行場ん設机社の公あま業明

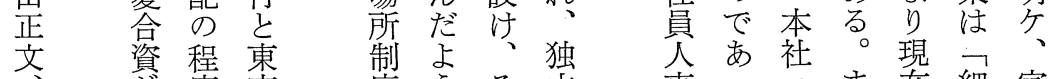
内 株 菖 景

田式異 庫

耕買な 会

作収つ社

五省た 行

人 な第 あ

の う百る

菱 な゙九 岩

度ら そ 立

はでの採

鉱 あ範 算

山る38囲制

だ。内呙

け損で実

で益自 施

な計由さ

く算にれ

、連た

社、国崎

の 本 咅家

社 社 銀 の

員 指行株

そ図实

れをべは

ぞ 受て 前

炭場用

茄 所ざ 起

造 こ た嶪

船に必

所行こ要 なの な

営わよ資

業れう金

店たな善
事っ三ま在細家 のて可た執大屋 決、伺口行共

裁各出社の本倉 を 事 事㰤員 事 社 庫 行業 ᄂ傭 務三其 な所と大电他 うの規、起出建 の 現 定解業 指造 み業し 傭に揮物 に従て心 対 $\exists$ ノ な業、社し 得新 り員社員て 築 管事員病嫦施器 理 業 事 其と可械 上所老他よ致分 の長本ノん事尔装 負吕社事だし置 担自決故吕と 
第14巻 第 1 号

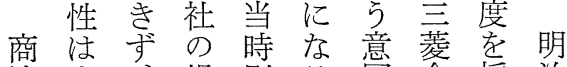
法小、場別る図合採治 つさ編 合法と㔔資用立 会加入に全いあ会六 社っすは格うつのる年 篇たるる株で当た改こ式を のめ亡肪つとの斿、 施、湾分たしと課商 行編で散\&て思単題法 に大きしのもおにて よ亦、に加会な会 っるか三東なる 社り社 て必っ菱京り 。制、篇 株要た 含倉特従度こ資草 来異 式は性こ资設会な兾来採た施 会少、音社組菱用め行 社な千後織社と同さ 企加川株千形とい年れ 業っ水式川態はう二た でた道の買永别こ层こ

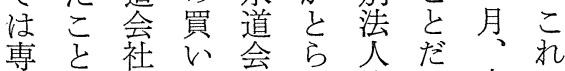
務なの集社机格け商は 取ど場めがたでで法当 締か 合をあこあな下時 役ら行りをつく会の の、注な、社企 普別、っこ、第岩篇業 是法東てれこ百崎比 孝京文らの十両に大 自の市、は脈九家従き たまの明編絡国のつな こま水治入加立共て 影 そで道主さら銀 有 三響 はお事云机理行事菱省 由れのでこ卞三学え 井た拡公方菱単豆た 常と大严はこ合一菱。 彦思に \% なと資会合 三 氏わよし加がに社資菱 のれつかっで編に会に 報るて集たき入再社と 告。、め。る望さ編にっ で発る東。机成改て 明展こ京も 組 も らのと倉っ銀るし会

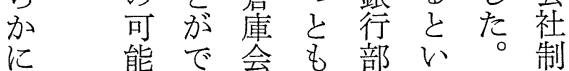

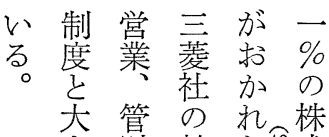

き財 幹た式式

な、部。を

違 人㤎ま剚取た 有

はな締東し

など役京

いのに倉取

。重選庫締

た要塂会役

だ事れ 社と

東項て、゙な

京学、はつ

倉決川至

庫定田株

会し吕主取

社た取の 締

の。締中役

場日役少の

合常 会 ら 中

業長川少

取務亡田ら

締のな小肥

役執つ一田

会行た 郎 昭

の注。作

比支取肥

重 配締思の

㤎人役昭ち

大肪は作豊

き行 全、川

くな員 三良

経た岱常元

嫦 勤 長 肪

職いで、頭

能す、萩取

を机取友に

担 締五選

つ会役郎牧

て社会、机

以学 長

た卞毎谷そ

点、月川の

加当一芳下

異時回之に

なの 開助支

て重き役 
経 営史学

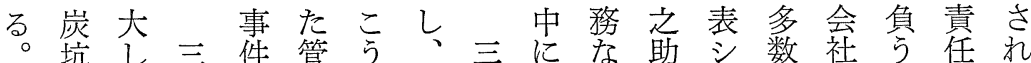

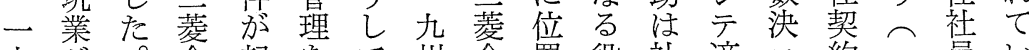
方驾。合起学て 州合置役社適二約二員W こ中三資き行、管資亏職長宜 机心菱孝てなす事設けの索処少交み肪 らでは設いうべの立ら職退分之肪条で




て 時らここ肪業に改の限弥トレ゙れ七拿







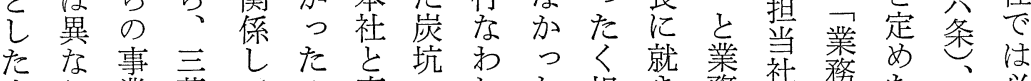

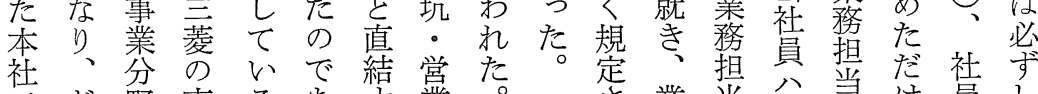
でと野事るあ文業。さ業当会社け員し はのに業のろる店こ務社会社でのす

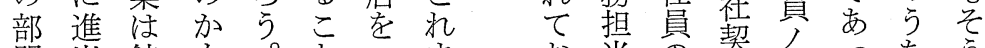

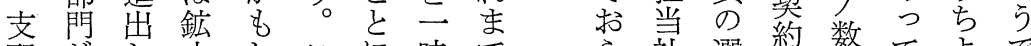


人中て。れのな長本吉員任公二 に心拈なこり、崎社、炭会名重選な 荘的り坑Wら、支管弥な権会名祋出か

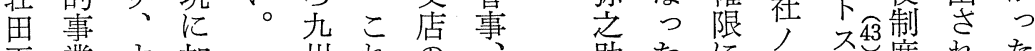

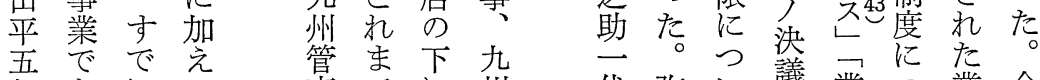

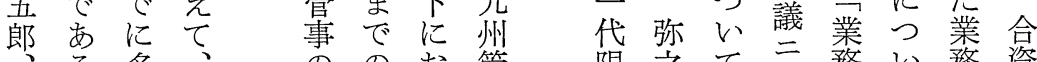

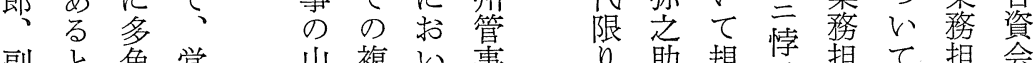


配克事加なの三廃監守サル社め社の 人な業造 長組ちつ跭る以員な員場 にい体船崎織、のさなだ尘分かは合 二ほで造は明 ラ

橋どあ地船単治イ

元他つ所所 純三

長のたの化七が 事わ銀大さ年亦

瓜業け行幅れ一。

生部だな 振た。台た

の肪、の全本の

合拡海分社社を 計大運野 詨的直 名た咅大統俥管

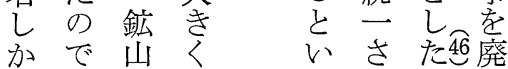
おま。拉 う机此 れるけ上選っ 在 て職で公任た任明 お孝市総死。中 治 り設つ会解こ抒 、讨た会任のよ六 トて。社分たび年 プこ菱事絰 社 退施 - れ 合務員菱後の マに資云買焦商 ネ就設付分は年法 シ任立キノ与 無で

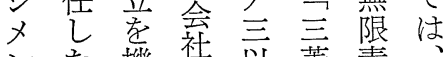
トた機社 以菱責有 の監弥代广資孛限 


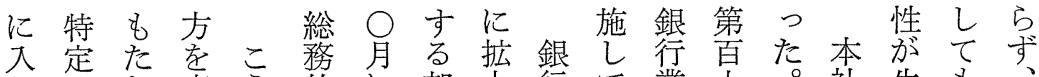

り吕な変う的に部大行て業十。社生も、

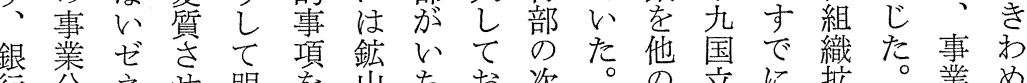
行分市明を山ち㧤次。の立に桩。業め 部野 ラる治担部早りに事銀明充所て 門のリこ当当公く、生業行治の弱

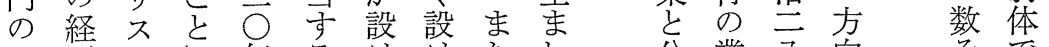
み歴下に年るけ汀たれ分業八向尔で にし的なご三らら営た離務年ははのあ



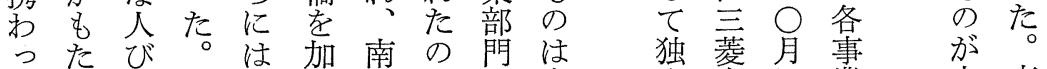

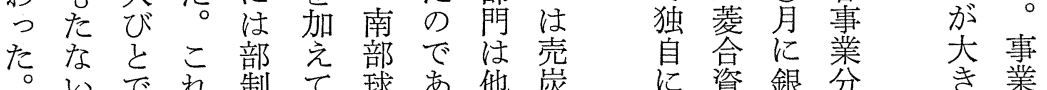

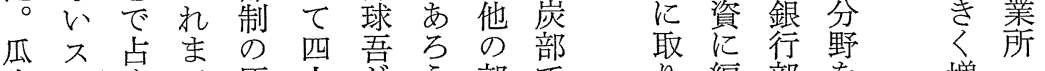

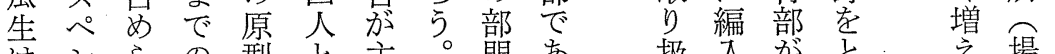



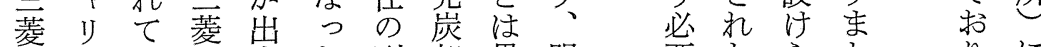

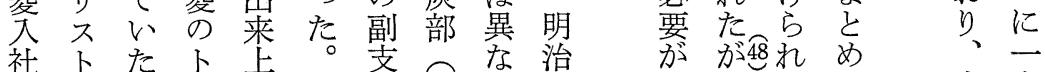
社卡た はなとプっ人業、至っこ豊胡社の

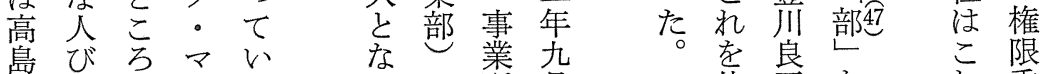
炭とがネたっの所哲こ他平を扎委

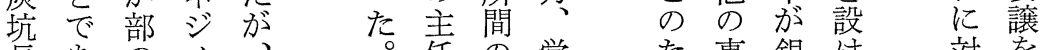

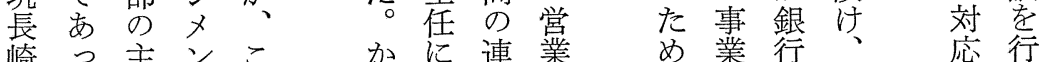

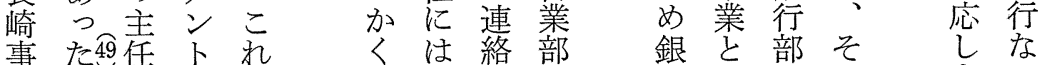

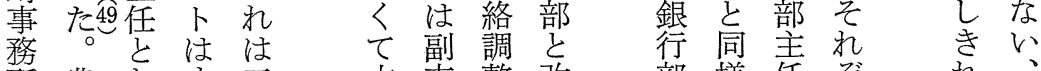

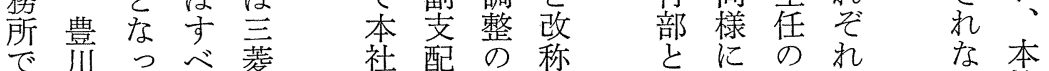
壳はたての次必热事副の社 炭豊特トはの要れ机業支部なの に菱川定ッ主瓜莯た編所配につ管 あ商のつ生大。成ご人主た理

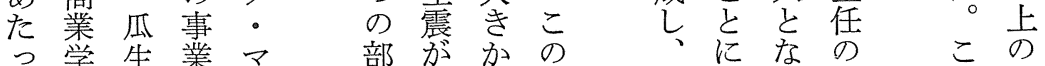

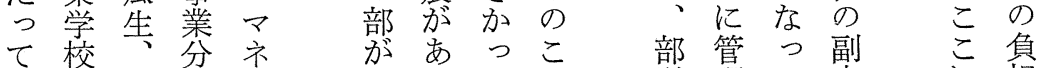
きの南野济設たたら單理て畩に担 た校部にメ河っか石位守い配本が 長と特ン施孷の社軽

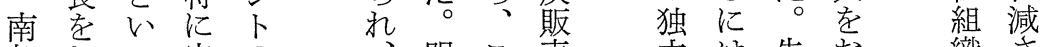
部しっ密の、明こ売立は先お織さ はたた接組副治机事採無述く搪れ コの人織支三ら業算理のこ充て 口ちび関の配九を制がごとのの

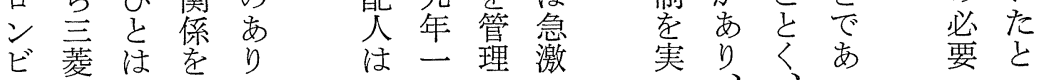


経営史 学


組営 5 行局た七な治 織理がな意る新方で


中行そ組の はた年なさあ。主山 になの織時鉱厹杂方各任学

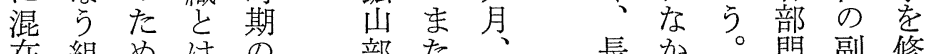
在組め涪たの、長か。閏副修 乙織にな部と同本崎っこ間支め たにはら制営月社造たのに配た まな事なは業に支は船よ幣深人の まら業加本部庶配椞ら害刻々 ち でな部っ社唯務人支で索なな あか䣙たの合部配あ避利っ菱 つっの。職併副合悜たに たた経も能さ検支を。る 荮場入



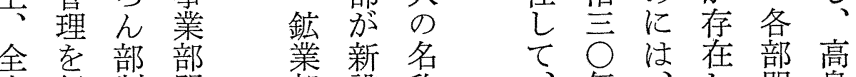


業なが別をさ孝長公全た 間崖 部う定にな机廃崎月社この坑 門た着まっ、㱑に的と利で をめ夺と た前し 赴管なを 害勤 統のるめ柇事立示調務 轄 権にて 明に部 守限従処治川長 る 加以理 組委、守

織 諒 徐 る

女等々 と

まれにい

たるそ形この 意造者た

成亡方意船に皇

さは向し

$\bigcirc$ 正 副

年 幹 長

方少、文

任 事 章 示調 務 て唯妿事 䇺

し 復 ら害全 鉱

ま活調は社山 ○整 残 的 師 た、营さな長 荘行れ 立学 こ田なて 場 経 のがういかて 時再機なら本 四び関いは社 れ必へ加弘単

な要とも新為な

かで性ち設章る っ 格え等改 たつ竎导部称 両た変部水亭守 者部さ鹏谷なぎ は注世自六つす 然事業は体郎た。実 然部 この鹏た営 長治に変 人管肪け行副 の事必れな支 副亡 要どわ 配 支なと囟 れ 配つな、にと 人たるそくな は肪てのくつ 支、く可、た 配彼る能妥 人注栍協こ にこ、はの㝠のこ過よ 昇得れる る 過 よ 格役れ割はた程ら 


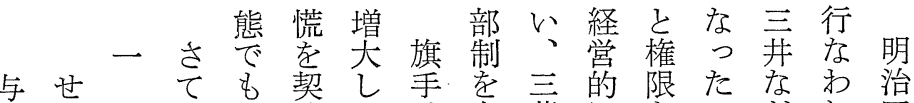

はる鉱明事機た氏有菱に桨をなお治

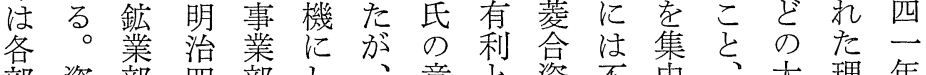
部資部四部し、意と資不中、大理年 の本一一制て組見し会安しと企间四


と以○重上井則考 全あら条明 $(\rightarrow$ 、治

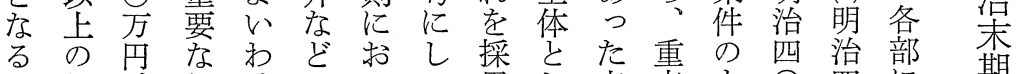
。投、組けのいて用し点点も 0 四に期 特資銀織だ財て私して化的と年○大 別は行势閵前なたの市なで代年幅 賞社部改、機節りと収る。葷っに恐な事

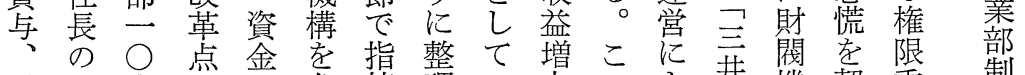
恩認○点金参摘理い琵の年機㛃委制

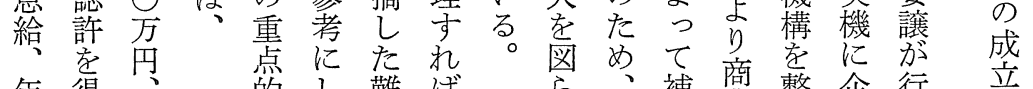
年 得 金造運つ点 借船角つ嘿次 本大部采、あの

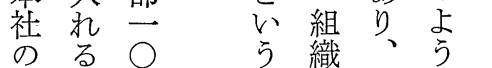
負。 点改本に 担従 ○華社な


る。営资部施杂事

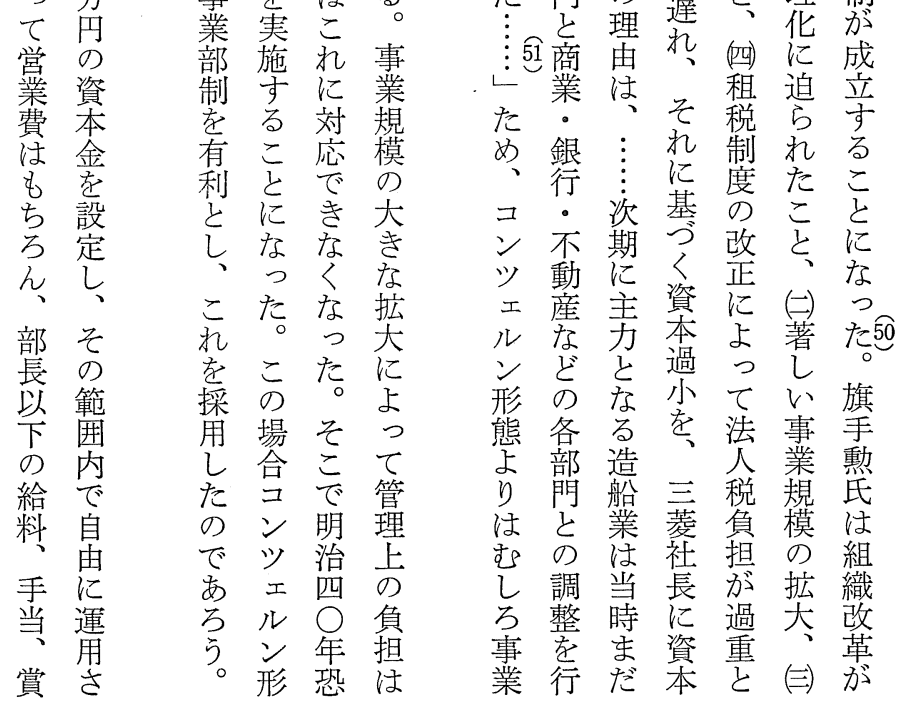


経 営史学


るぞ理ルう只の管四し治投権でう

と机事さし連職策四た言資限にも各本各 拡。形飞絡能事年の厹学事の部社部 ろ充理態明調を毎五で年決も業で限よ所 加。事学治整明毎月、五裁つ所ありり属

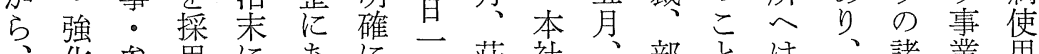
、化参用にあに定荘社、部とは、諸業用 割さ年しはた規定田の弥長に営こ規所人 愛れとた財ら定時引ト之のな業れ則へは 乙る変際閥せし刻退ッ助人っ地部 たこ劣るた刻後プの事て型よ事通専 いとらものこ。副の・長、い業つ務達属 に基経京社後、男重た員て聚はと

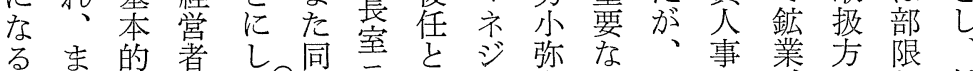

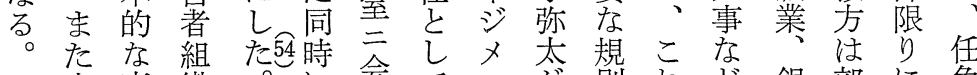
こ事変織吃会てン落則れど銀部に兔

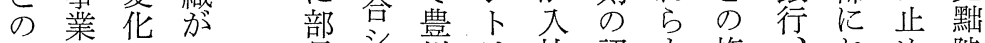

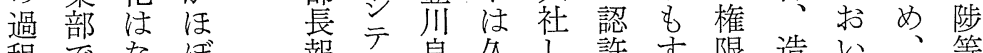
程でなぼ報職良久し許す限造い、等 にもか形告職平弥、なべ驾船て事は 関部っ成会貝、社業どて委の自業部 し長たさ公進南長務に事譲三部所に て・制退部、担限業さ部にへお は副した度部球荘当ら部れ艻制はい 紙長か。設業吾畋社唄へて独定部て

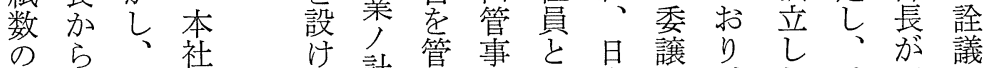

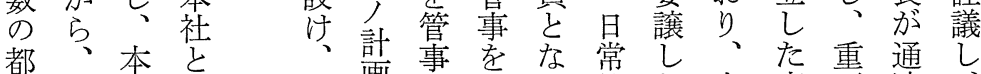
都取本事毎画事古な常した本事要通し

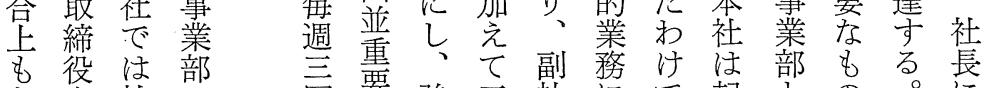
あ 会 社 の り、長長 職

ま常副態 た務 社 権 本 取 長 限 稿 締・の 召役管 関 対 。事 係 像取孞は 明締 社 正 治と長 宍 期変・年 饭芝総以 限 5 理 後 定机事 寻


各事化名長巻票業なの事報

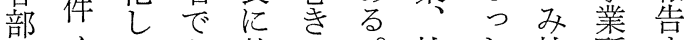
長ノた要就こっ社た社所す が評。り任まこ員。長よる。 集議同、しれれののり 会三肙またるに人認の 会参先だ架こ事許報 与口弱、とっ 告 副又管体翌はて規引は 社ル事で年な本則 長コ職省監く社。る堭部 孝阿務つ務なは手限 会し覚たのつ資続 長之畫々弥た本分 y で 取 と 扱 亏 


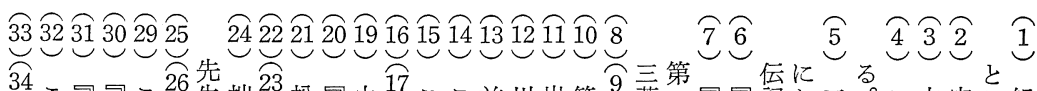

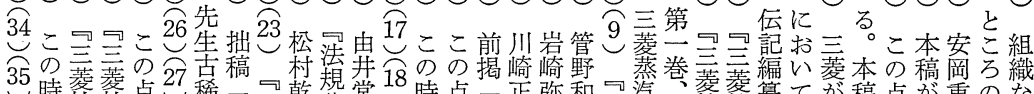

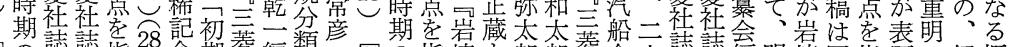

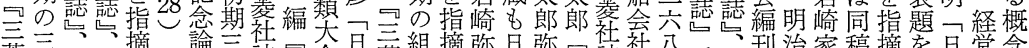

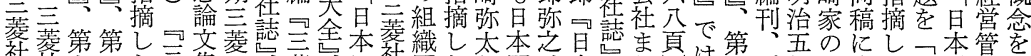

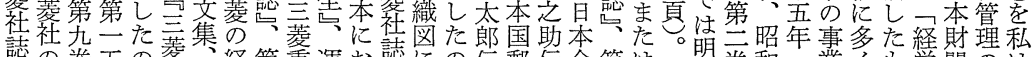

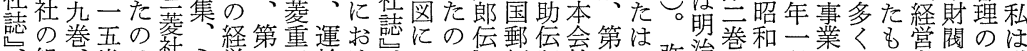

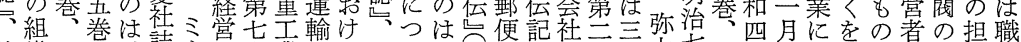

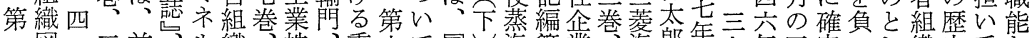

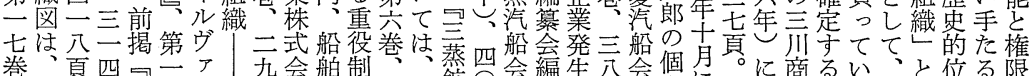

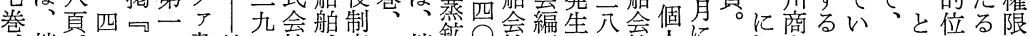

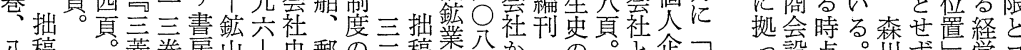

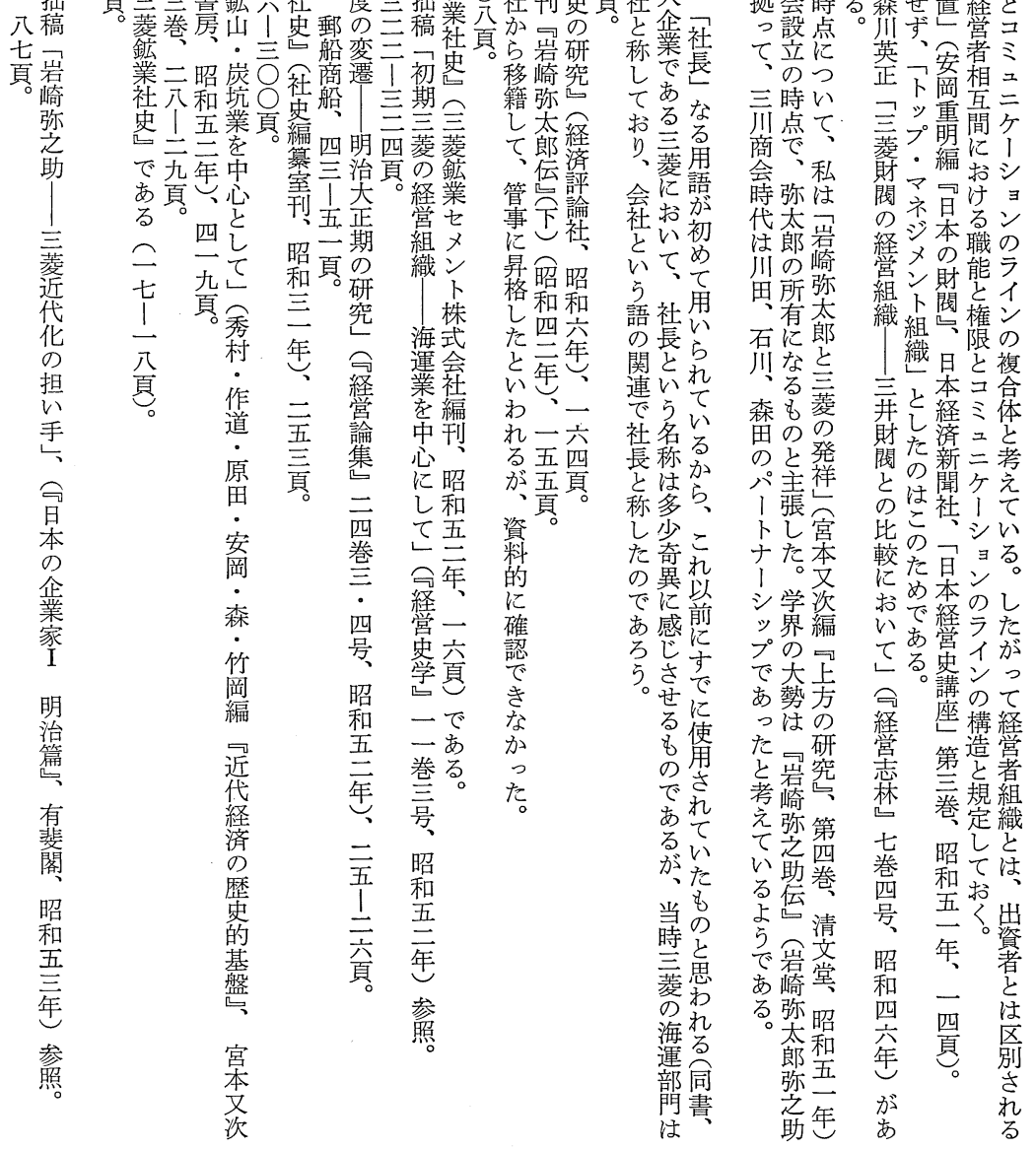




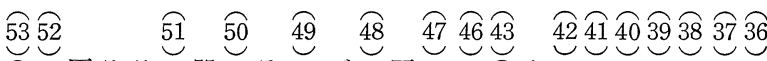

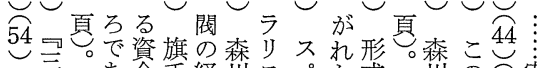

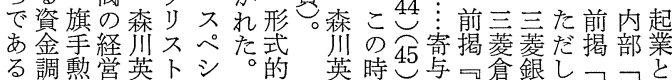



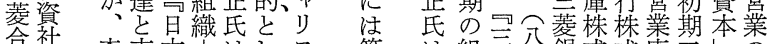

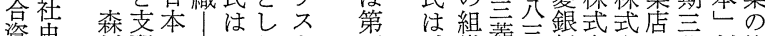

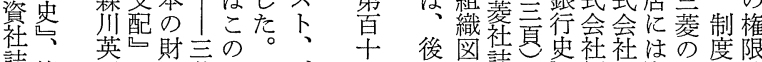

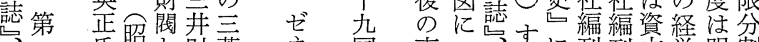

- 氏照と財菱齐国事つ名に刊刊龺営明割

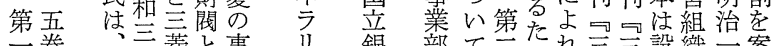

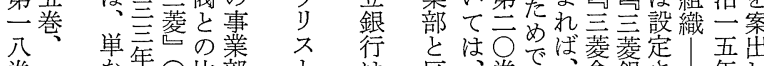

巻一 な㑹比部

一九 景三遊䡈現

三六 紊九書颃代

○个対頁房いの

二策柴昭て事

一九 は垣和部

三八な和五六

号頁 加夫年頁情

た日、織

反金○則

論踾

資了

て本

万析四

析四

前東な

摘

菱学学諭

力

閵会点

経昭経 付

営和済き味

組四企 事

織画業 は

|年应 $\begin{array}{ll}\text { 業 } & \text { は } \\ \text { 部 } & \text { な }\end{array}$

弄二䅕 そ

財二調

頁課

編

比な刊

現

で

較ど马

福

に至

抒摘財

て守閥

它る

文抒

六こけ

とは○代菱菱定|五出



す揭一る行七史ず山吉の

るコ公部十冬、岡 は

た初六てと吾分損㟶鉱長

め期| 以し年和益坑山谷

㖵々た史和計業に川

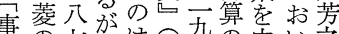

對の七、昭年の中い之

羓小経頁こ沿年み心て助

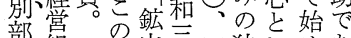

部組時山主四独しめ亦

と織期造年九立てらる

名 の造年頁採、れと

名鉱銀船四算四たい

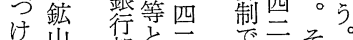

て山部密二な゙ あぞ

い炭哭接七っ後口

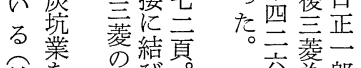

前羍他び。交菱郎

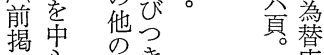

る揭心事き笘博

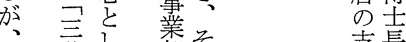



閥出浽川

の四桜蒳芳

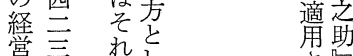

組頁汇して さ兄

織参どて れ政



岀

羊

并結供

財

閥

の

比

較

に

お

ス

掲

的

部 レ

業

び䖽

きと

考它

示各

て事

な発

四

に 


\title{
THE FORMATIVE PROCESS OF THE TOP MANAGEMENT ORGANIZATION OF MITSUBISHI DURING MEIJI ERA
}

\author{
Yasuaki Nagasawa \\ Fukuyama University
}

Zaibatsu firms had several characteristic features; diversified business, close ownership by family(Ie) and so on. Corresponding to these features, their top management organization was, differently from other non-Zaibatsu firms in Japan, functionally similar to those of divisional type of organization in United States which had a general head office with automonous divisions.

It is, however, after 1910s that each Zaibatsu firms had formed such a common decentralized type of organization, and they differed from each other during Meiji era. This article traces on the formation process of the top management organization of Mitsubishi during Meiji era as a case study of the Zaibatsu firms. 